Research Article

\title{
Stopped Flow Kinetics of MnII Catalysed Periodate Oxidation of 2,3-dimethylaniline - Evaluation of Stability Constant of the Ternary Intermediate Complex
}

\author{
R. D. Kaushik*, Richa Agarwal, Priyanka Tyagi, Om Singh, Jaspal Singh \\ Department of Chemistry, Gurukul Kangri University, Haridwar-249404, India
}

Received: 3rd October 2014; Revised: 4th December 2014; Accepted: 15th December 2014

\begin{abstract}
The formation of ternary intermediate unstable complex during the oxidation of aromatic amines by periodate ion catalysed by $\mathrm{Mn}^{\mathrm{II}}$ has been proposed in case of some anilines. This paper is the first report on stopped-flow kinetic study and evaluation of stability constant of ternary complex forming in the $\mathrm{Mn}^{\mathrm{II}}$ - catalysed periodate oxidation of 2, 3-dimethylaniline (D) in acetone-water medium. Stop-flow spectrophotometric method was used to study the ternary complex formation and to determine its stability constant. The stop-flow trace shows the reaction to occur in two steps. The first step, which is presumably the formation of ternary complex, is relatively fast while the second stage is relatively quite slow. The stability constant evaluated for $\mathrm{D}-\mathrm{Mn}^{\mathrm{II}}-\mathrm{IO}_{4}$ - ternary complex by determining equilibrium absorbance is $(2.2 \pm 1.0) \times 10^{5}$. Kinetics of ternary complex formation was defined by the rate law $\left(\ln \left\{\left[C_{2}\right]_{\text {eq }} /\left(\left[C_{2}\right]_{\text {eq }}\left[C_{2}\right]\right)\right\}=k_{o b s . t}\right)$ under pseudo first order conditions, where, $k_{o b s}$ is the pseudo first order rate constant, $\left[C_{2}\right]$ is concentration of ternary complex at given time $t$, and $\left[C_{2}\right]_{\text {eq }}$ is the equilibrium concentration of ternary complex. (C) 2015 BCREC UNDIP. All rights reserved.
\end{abstract}

Keywords: Stopped flow kinetics; Stability constant; Ternary complex; Mn II catalysed; Periodate oxidation; 2,3-dimethylaniline

How to Cite: Kaushik, R. D., Agarwal, R., Tyagi, P., Singh, O., Singh, J. (2015). Stopped Flow Kinetics of MnII Catalysed Periodate Oxidation of 2,3-dimethylaniline - Evaluation of Stability Constant of the Ternary Intermediate Complex. Bulletin of Chemical Reaction Engineering \& Catalysis, 10 (1): 78 87. (doi:10.9767/bcrec.10.1.7621.78-87)

Permalink/DOI: http://dx.doi.org/10.9767/bcrec.10.1.7621.78-87

\section{Introduction}

Aromatic amines are used as intermediates in the manufacture of plastics, dyes, drugs, explosives, rubber, epoxy polymers, azo dyes, aromatic polyurethane products and pesticides [1]. These can come in contact with living organisms by inhalation, ingestion and skin contact and most of these are enlisted as carcinogenic and/ or toxic due to their genotoxic or cytotoxic properties [2,3]. It is of interest to study their

* Corresponding author

E-mail: rduttkaushik@yahoo.co.in (Kaushik, R.D) Tel. +917351739000 new reactions for understanding their role in physiological activities and for developing methods for their detection, estimation and treatment. Aromatic amines have been subjected to oxidation reactions by using oxidants like peroxydisulphate ion [4], benzimidazolium fluorochromate [5] and periodate, etc.

The kinetics and mechanism of the uncatalysed and $\mathrm{Mn}^{\mathrm{II}}$ catalyzed non-Malapradian periodate oxidation of some aromatic amines has been the subject of study during the past few years. In these reports, a binary unstable intermediate complex formation between aromatic amine and periodate has been proposed in the 
reaction mechanism of uncatalysed reactions [6-16]. Also, there are some reports available which propose the ternary complex formation between periodate, aromatic amine and $\mathrm{Mn}^{\mathrm{II}}$ in some reactions catalysed by $\mathrm{Mn}^{\mathrm{II}}$ [17-23].

In continuation to our studies on periodate oxidation of 2,3-dimethylaniline catalyzed by $\mathrm{Mn}^{\mathrm{II}}$ [23], and in order to make an attempt for the first time for evaluation of stability constant for the ternary intermediate complex being formed in this reaction, the results of stopped flow kinetic studies made on $\mathrm{Mn}^{\mathrm{II}}$ catalysed periodate oxidation of 2,3dimethylaniline in acetone-water medium are being presented and discussed in this communication.

\section{Experimental}

\subsection{Reagents and Chemicals}

The principal reagents used were sodium metaperiodate (Loba Chemie) (CAS no. 779028-5), 2,3-dimethylaniline (Aldrich) (CAS no. 87-59-2) and manganese sulphate monohydrate (Aldrich) (CAS no. 10034-96-5) (here-to-after referred as I, D and $\mathrm{Mn}^{\mathrm{II}}$, respectively). All

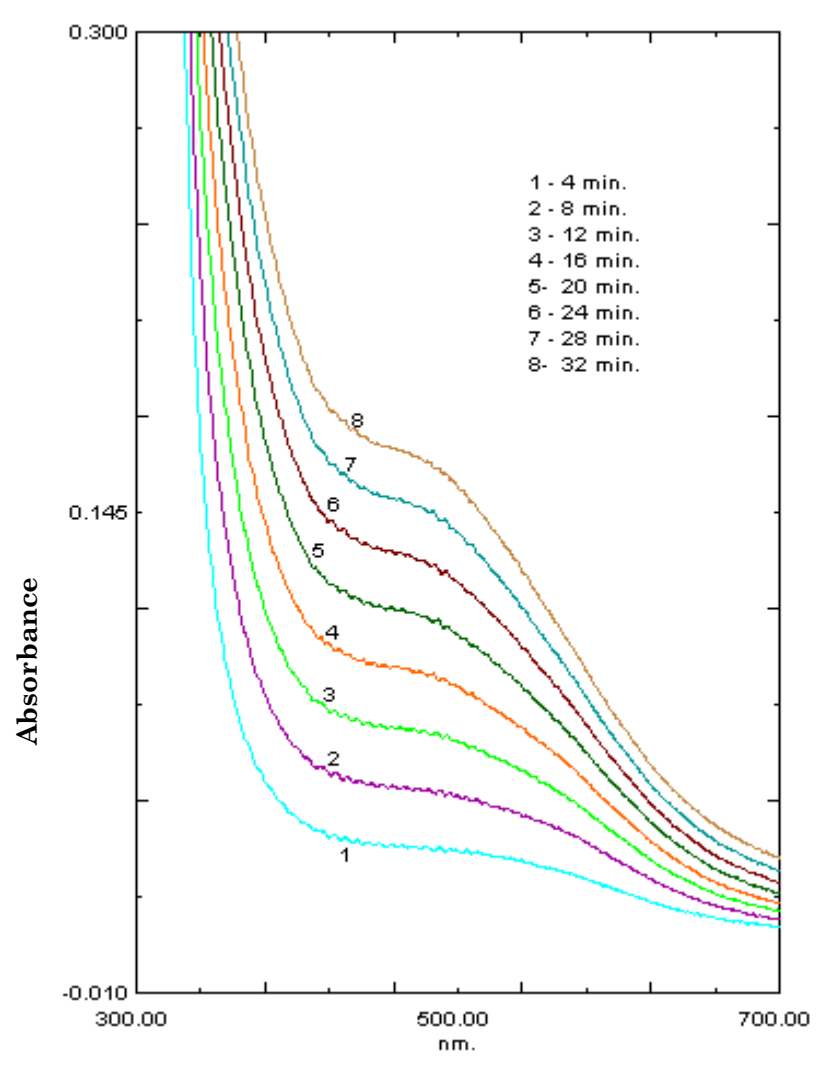

Figure 1. UV-VIS rapid scan at different time at $[\mathrm{D}]=2.0 \times 10^{-4} \mathrm{~mol} \mathrm{dm}^{-3},[\mathrm{I}]=2.0$ $\times 10^{-2} \mathrm{~mol} \mathrm{dm}^{-3}, \mathrm{pH}=6.0$, Temp. $=35 \pm$ $0.1^{\circ} \mathrm{C}$, acetone $=10.0 \%(\mathrm{v} / \mathrm{v}), \lambda_{\max }=470 \mathrm{~nm}$, time interval $=120 \mathrm{~s}$ other chemicals of analytical reagent / guaranteed reagent grade were used after redistillation / recrystallization. Triply distilled water was used for preparation of the solutions. Thiel, Schultz and Koch buffer [24], used for maintaining the $\mathrm{pH}$ of reaction mixtures, was prepared by mixing desired volumes of $0.05 \mathrm{M}$ oxalic acid (CAS no. 144-62-7), $0.02 \mathrm{M}$ boric acid (CAS no. 10043-35-3), 0.05 M succinic acid (CAS no. 110-15-6), 0.05 M sodium sulphate (CAS no. 7757-82-6) and 0.05 M sodium tetraborate decahydrate (CAS no. 1303-96-4). Acetone (E. Merck) (CAS no. 67-64-1) was used for preparation of reaction mixtures.

\subsection{Kinetic Procedure}

All absorbance measurements were made on Shimadzu double beam spectrophotometer (UV-2450). The reaction was initiated by adding temperature equilibrated $\mathrm{NaIO}_{4}$ solution of known concentration to the reaction mixture containing $\mathrm{D}, \mathrm{Mn}^{\mathrm{II}}$ and buffer. The temperature of reaction mixture was maintained in the uvvs spectrophotometer with the help of an inbuilt temperature control unit, Shimadzu TCC-

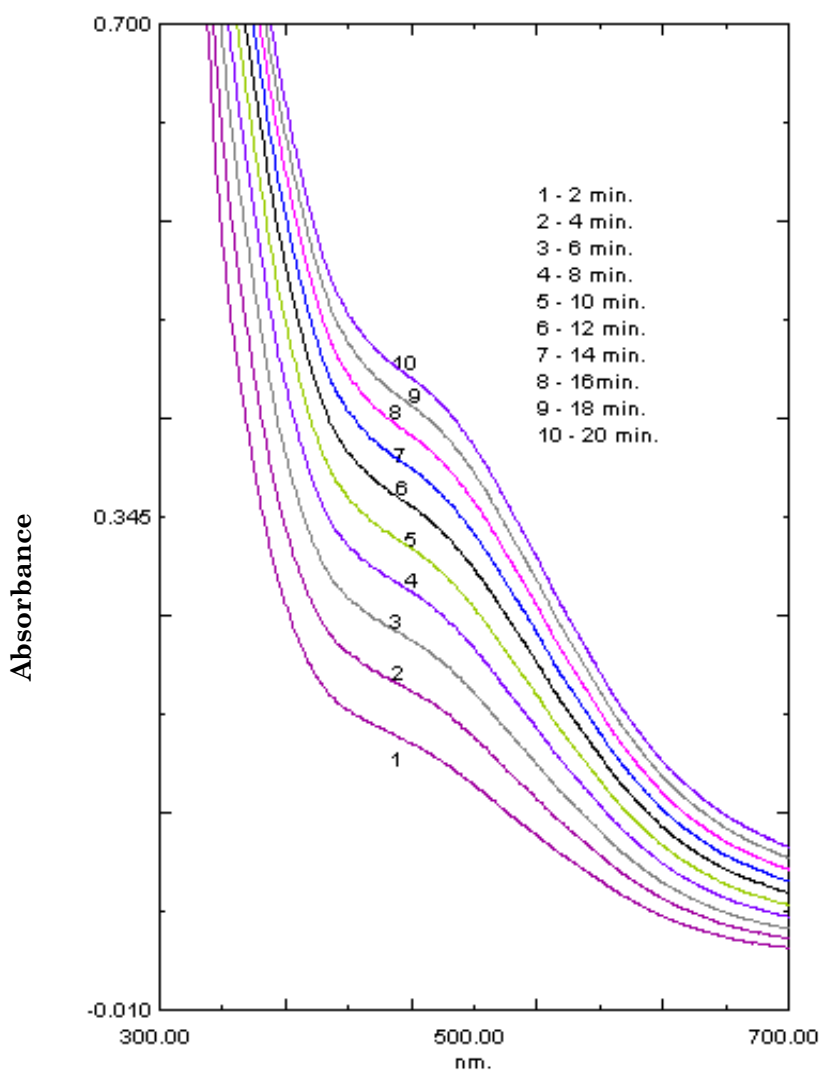

Figure 2. UV-VIS rapid scan at different time at $[D]=2.0 \times 10^{-4} \mathrm{~mol} \mathrm{dm}^{-3}, \quad[\mathrm{I}]=2.0 \times 10^{-2} \mathrm{~mol} \mathrm{dm}^{-3}$, $\left[\mathrm{Mn}^{\mathrm{II}}\right]=7.28 \times 10^{-6} \mathrm{~mol} \mathrm{dm}^{-3}, \mathrm{pH}=6.0$, Temp. $=35 \pm$ $0.1{ }^{\circ} \mathrm{C}$, acetone $=10.0 \%(\mathrm{v} / \mathrm{v}), \lambda_{\max }=470 \mathrm{~nm}$, time interval $=60 \mathrm{~s}$ 
240 , with an accuracy of $\pm 0.1^{\circ} \mathrm{C}$. The absorption maximum $\left(\lambda_{\max }\right)$ of the reaction mixture was $470 \mathrm{~nm}$. The value of $\lambda_{\max }$ remained unchanged during experimental conditions as shown in Figures 1, 2 and 3. For stopped flow kinetics study, the progress of the reaction was followed by recording the absorbance change with time at $470 \mathrm{~nm}$ on stopped flow apparatus (Applied Photophysics - Stopped Flow SX-20). Desired temperature $\left( \pm 0.01{ }^{\circ} \mathrm{C}\right)$ was maintained with the help of an automatic high precision thermostatic control (Thermo Scientific NESLAB RTE7).

Substrate solution was prepared by mixing known amounts of $\mathrm{D}$ (in acetone), $\mathrm{Mn}^{\mathrm{II}}$, acetone and buffer solution. After baseline setting to zero absorbance by emptying both syringes loaded with buffer solution, one of the syringes was loaded with periodate solution of known concentration, while other syringe was loaded with substrate solution. The reaction was initiated by emptying the syringes. Collected data were treated by the software (SX-20, Pro-data) for determining the pseudo-first order rate constants.

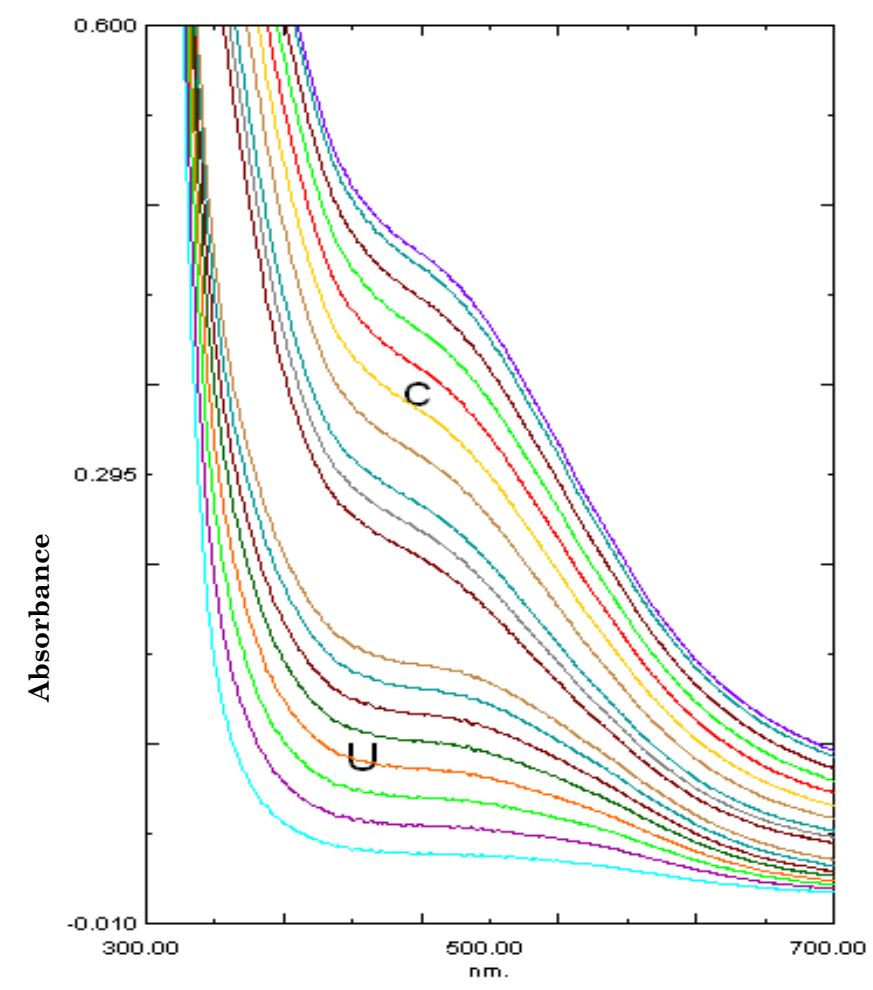

Figure 3. Compression of UV-VIS rapid scans of unanalyzed and catalyzed. Reaction at $[\mathrm{D}]=$ $2.0 \times 10^{-4} \mathrm{~mol} \mathrm{dm}^{-3} ;[\mathrm{I}]=2.0 \times 10^{-2} \mathrm{~mol} \mathrm{dm}^{-3}, \mathrm{pH}=$ 6.0, Temp. $=35 \pm 0.1{ }^{\circ} \mathrm{C}$, acetone $=10.0 \%(\mathrm{v} / \mathrm{v})$, $\lambda_{\text {max }}=470 \mathrm{~nm}$; $\left[\mathrm{Mn}^{\mathrm{II}}\right]=7.28 \times 10^{-6} \mathrm{~mol} \mathrm{dm}^{-3}$ (for catalysed reaction only). $\mathrm{U}$ and $\mathrm{C}$ represent the scans for uncatalysed and catalysed reaction, respectively.

\section{Results and Discussion}

\subsection{Preliminary Investigation}

The absorption maxima of the reaction mixture containing $\mathrm{Mn}^{\mathrm{II}}, \mathrm{D}$ and I differed widely from that of the mixture containing only $\mathrm{D}$ and $\mathrm{NaIO}_{4}$. Further, absorbance measurements indicated there to be no observable reaction between $\mathrm{Mn}^{\mathrm{II}}$ and I or $\mathrm{Mn}^{\mathrm{II}}$ and $\mathrm{D}$. On mixing $\mathrm{D}$ and I, the solution turned light yellow and the nature of spectrum (Figure 1) was quite different from the individual spectra of D and I indicating the formation of complex or adduct, D I. The $\lambda_{\max }$ of this adduct was found to be 470 $\mathrm{nm}$, which did not change with time, as shown in Figure 1.

Our purpose was to study the kinetics of periodate oxidation of $\mathrm{D}$ in presence of $\mathrm{Mn}^{\mathrm{II}}$, which is known to be a catalyst for this system [23]. Therefore, the rapid scan spectra of the solution containing $\mathrm{Mn}^{\mathrm{II}}, \mathrm{NaIO}_{4}$ and $\mathrm{D}$ were recorded and are shown in Figure 2. This mixture is yellow in colour, which deepens with progress of time. A comparison of spectrum of D $\mathrm{Mn}^{\mathrm{II}}$ - I system with that of I - D system indicates the formation of a ternary complex, $\mathrm{Mn}^{\mathrm{II}}$ - D - I, when $\mathrm{Mn}^{\mathrm{II}}$ is present. Although, $\lambda_{\max }$ is same (470 nm in Figure 3), but the molar extinction coefficient of ternary complex is high.

The reaction between periodate and $\mathrm{D}$ in presence of $\mathrm{Mn}^{\mathrm{II}}$ has been shown to be first order in each reactant and catalyst as already reported [23]. So the kinetics was studied under pseudo first order conditions.

\subsection{Stability Constant of D - MnII - I Ter- nary Complex}

Stop-flow spectrophotometric method was used to study the ternary complex formation and to determine its stability constant. In all the experiments, both $[\mathrm{I}]$ and $[\mathrm{D}]$ were in large excess (at least ten times) over [ $\left.\mathrm{Mn}^{\mathrm{II}}\right]$, and [I] was in excess over [D]. The stop-flow trace, as presented in Figure 4, shows the reaction to occur in two steps. The first step, which is presumably the formation of ternary complex, is relatively fast with $70 \%$ reaction occurring in $\sim 200 \mathrm{~s}$; the second stage is relatively quite slow. The ternary complex attained equilibrium in about $500-1500 \mathrm{~s}$ depending upon the reactant concentrations. The relatively faster rate of the first stage allowed us to assume maximum absorbance recorded in each stop-flow run to be equal to the equilibrium absorbance of the ternary complex. The values of equilibrium absorbance $\left(A_{e}\right)$ are given in Table 1.

Ternary complex was formed in stop-flow 
experiment, when a solution containing $\mathrm{Mn}^{\mathrm{II}}$ and $\mathrm{D}$ was mixed with solution of $\mathrm{NaIO}_{4}$. The formation of a complex can be written as in Equation (1).

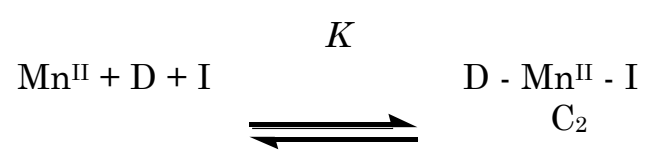

where $\mathrm{C}_{2}$ represents the ternary complex, D $\mathrm{Mn}^{\mathrm{II}}$ - I.

The probable mechanism of the formation of ternary complex can be given in Equation (2).

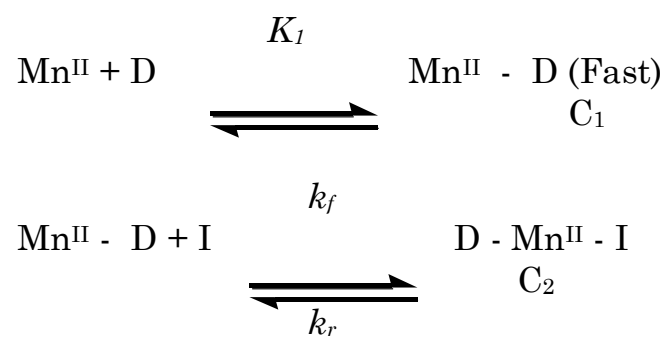

Subsequently, the ratio $k_{f} / k_{r}$ has been used to represent $K_{2}$, the equilibrium constant of reaction (Equation (3)).

The spectra of $\mathrm{D}, \mathrm{I}, \mathrm{Mn}^{\mathrm{II}}$ and reaction mixtures for catalysed / uncatalysed reactions show that the only principal species absorbing at 470 $\mathrm{nm}$ is ternary complex. At this wavelength, $\mathrm{Mn}^{\mathrm{II}}, \mathrm{D}, \mathrm{Mn}^{\mathrm{II}}$ - D and $\mathrm{Mn}^{\mathrm{II}}$ - I display no significant absorbance. However, the D - I adduct absorb at $470 \mathrm{~nm}$, but its absorbance is not sizable and, therefore, can be ignored.

Table 1. Equilibrium absorbance for [D- $\left.\mathrm{Mn}^{\mathrm{II}}-\mathrm{I}\right]$ ternary complex formation. $\left[\mathrm{Mn}^{\mathrm{II}}\right]=7.28 \times 10^{6}$ $\mathrm{mol} \mathrm{dm}{ }^{-3}, \mathrm{pH}=6.0$, Temp. $=35 \pm 0.01{ }^{\circ} \mathrm{C}$, acetone $=10.0 \%(\mathrm{v} / \mathrm{v}), \lambda_{\max }=470 \mathrm{~nm}$

\begin{tabular}{ccc}
\hline $\begin{array}{c}{\left[\mathrm{NaIO}_{4}\right]} \\
\left(\mathrm{mol} \mathrm{dm}^{-3}\right)\end{array}$ & $\begin{array}{c}{[\mathrm{D}]} \\
\left(\mathrm{mol} \mathrm{dm}^{-3}\right)\end{array}$ & $\begin{array}{c}\text { Absorbance at } \\
\text { equilibrium } \\
\left(\mathrm{A}_{\mathrm{e}}\right)\end{array}$ \\
\hline 0.010 & 0.0002 & 0.082 \\
0.015 & 0.0002 & 0.097 \\
0.020 & 0.0002 & 0.102 \\
0.025 & 0.0002 & 0.117 \\
0.030 & 0.0002 & 0.125 \\
\hline 0.010 & 0.0001 & 0.052 \\
0.010 & 0.0002 & 0.082 \\
0.010 & 0.0003 & 0.126 \\
0.010 & 0.0004 & 0.156 \\
0.010 & 0.0005 & 0.184 \\
\hline
\end{tabular}

If the absorbance values at pre-selected wavelength, $470 \mathrm{~nm}$, are measured in solutions containing different [D] and [I] but at fixed $\left[\mathrm{Mn}^{\mathrm{I}}\right]$, it can be shown that $[25,26]$ :

$$
A_{e}=-\left(A_{e}-A_{0}\right) / K[\mathrm{D}][\mathrm{I}]+A_{\infty}
$$

where $A_{e}$ is the absorbance of the ternary complex at equilibrium, $A_{\infty}$ is the absorbance when $\mathrm{Mn}^{\mathrm{II}}$ is fully present as ternary complex, and $A_{0}$ is the absorbance of $\mathrm{Mn}^{\mathrm{II}}$ in the absence of $\mathrm{D}$ and I. $K$ is the overall stability constant and based on Equation (1) is defined by Equation (5).

$$
K=\left[\mathrm{Mn}^{\mathrm{II}}-\mathrm{D}-\mathrm{I}\right] /\left[\mathrm{Mn}^{\mathrm{II}}\right][\mathrm{D}][\mathrm{I}]
$$

where, $\left[\mathrm{Mn}^{\mathrm{II}}-\mathrm{D}-\mathrm{I}\right]=\left[\mathrm{C}_{2}\right]_{\mathrm{eq}}=$ equilibrium concentration of ternary complex, $\left[\mathrm{Mn}^{\mathrm{II}}\right]=$ equilibrium concentration of uncomplexed $\mathrm{Mn}^{\mathrm{II}}$. [D] and [I] are initial concentrations of $\mathrm{D}$ and periodate, respectively.

On replacing $\left[\mathrm{Mn}^{\mathrm{II}}-\mathrm{D}-\mathrm{I}\right]$ by $\left[\mathrm{C}_{2}\right]_{\mathrm{eq}}$, Equation (5) becomes Equation (6) or (7).

$$
\begin{aligned}
& K=\left[\mathrm{C}_{2}\right]_{\mathrm{eq}} /\left[\mathrm{Mn}^{\mathrm{II}}\right][\mathrm{D}][\mathrm{I}] \\
& {\left[\mathrm{Mn}^{\mathrm{II}}\right]=\left[\mathrm{C}_{2}\right]_{\mathrm{eq}} / K[\mathrm{D}][\mathrm{I}]}
\end{aligned}
$$

By mass balance, total $\mathrm{Mn}^{\mathrm{II}}$ concentration, $\left[\mathrm{Mn}^{\mathrm{II}}\right]_{0}$ is given by Equation (8):

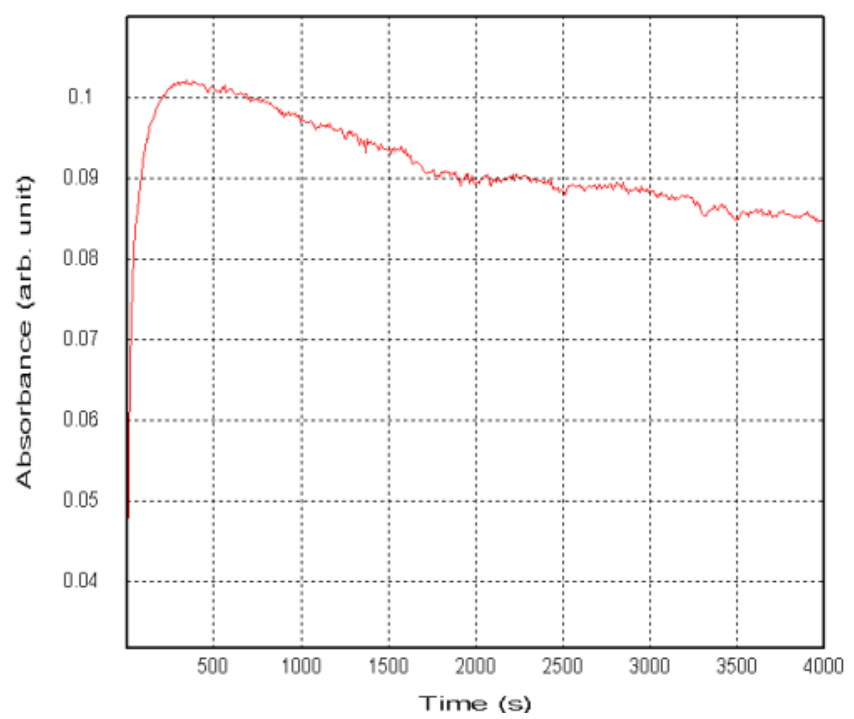

Figure 4. The complete kinetic profile (in terms of stopped flow trace) for $\mathrm{Mn}^{\mathrm{II}}$ catalyzed oxidation of $\mathrm{D}$ by $\mathrm{NaIO}_{4}$ at $[\mathrm{D}]=$ $2.0 \times 10^{-4} \mathrm{~mol} \mathrm{dm}^{-3}, \mathrm{pH}=6.0,[\mathrm{I}]=2.0 \times 10^{-2}$ $\mathrm{mol} \mathrm{dm} \mathrm{dm}^{-3},\left[\mathrm{Mn}^{\mathrm{I}}\right]=7.28 \times 10^{-6} \mathrm{~mol} \mathrm{dm}{ }^{-3}$, Temp. $=35 \pm 0.01{ }^{\circ} \mathrm{C}$, acetone $=10.0 \%(\mathrm{v} / \mathrm{v})$, $\lambda_{\text {max }}=470 \mathrm{~nm}$ 
$\left[\mathrm{Mn}^{\mathrm{II}}\right]_{0}=\left[\mathrm{Mn}^{\mathrm{II}}\right]+\left[\mathrm{Mn}^{\mathrm{II}}-\mathrm{D}\right]+\left[\mathrm{Mn}^{\mathrm{II}}-\mathrm{D}-\mathrm{I}\right]$

$$
\left[\mathrm{C}_{1}\right] \quad\left[\mathrm{C}_{2}\right]_{\mathrm{eq}}
$$

Since $\left[\mathrm{Mn}{ }^{\mathrm{II}}-\mathrm{D}\right]$ is assumed to be very small, it can be neglected in Equation (8).

$$
\begin{aligned}
& {\left[\mathrm{Mn}^{\mathrm{I}}\right]_{0}=\left[\mathrm{Mn}^{\mathrm{II}}\right]+\left[\mathrm{C}_{2}\right]_{\mathrm{eq}}} \\
& \text { or } \\
& {\left[\mathrm{C}_{2}\right]_{\mathrm{eq}}=\left[\mathrm{Mn}^{\mathrm{II}}\right]_{0}-\left[\mathrm{Mn}^{\mathrm{II}}\right]}
\end{aligned}
$$

Putting the value of $\left[\mathrm{Mn}^{\mathrm{II}}\right]$ from Equation (7) into Equation (10), we get:

$$
\left[\mathrm{C}_{2}\right]_{\mathrm{eq}}=\left[\mathrm{Mn}^{\mathrm{II}}\right]_{0}-\left[\mathrm{C}_{2}\right]_{\mathrm{eq}} / K[\mathrm{D}][\mathrm{I}]
$$

As already mentioned in the section 3.1 , absorbance measurements indicated no observable reaction between $\mathrm{Mn}^{\mathrm{II}}$ and $\mathrm{I}$ or $\mathrm{Mn}^{\mathrm{II}}$ and $\mathrm{D}$. The experiments were conducted separately by

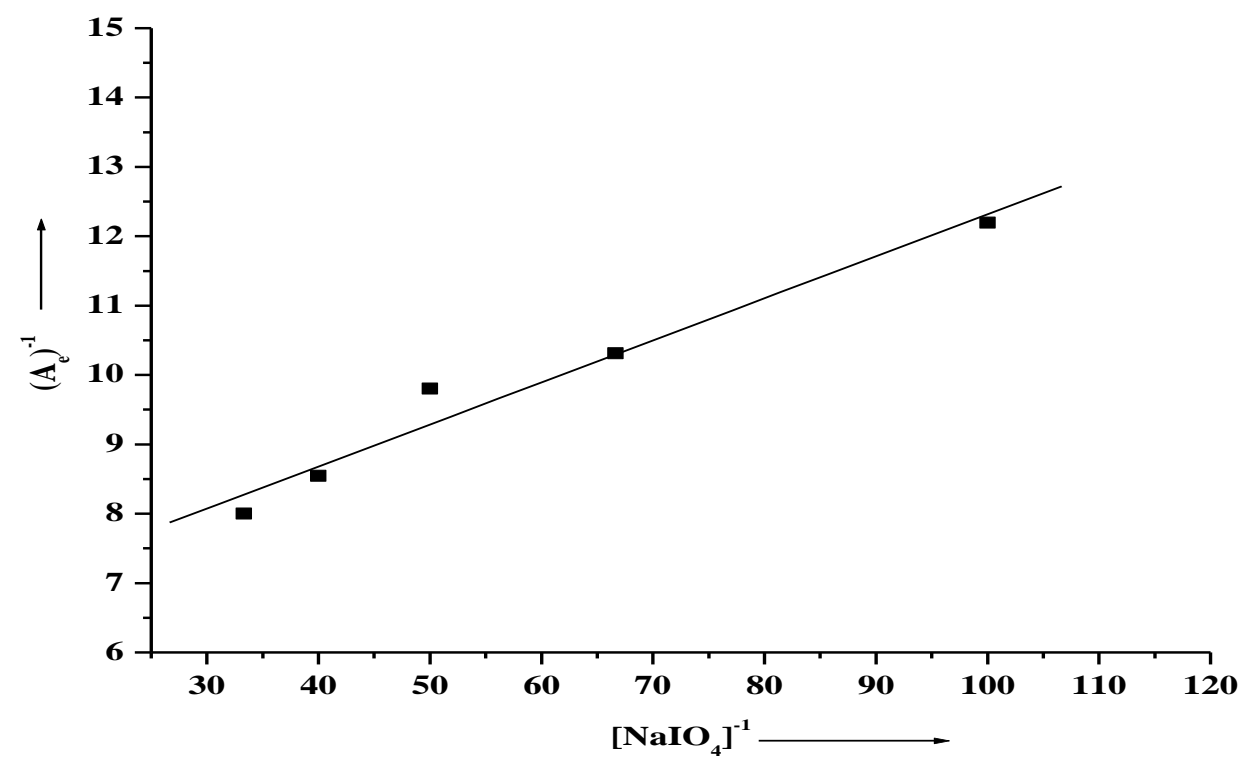

Figure 5. A plot $\left(A_{e}\right)^{-1}$ vs $[\mathrm{I}]^{-1}$ at $[\mathrm{D}]=2.0 \times 10^{-4} \mathrm{~mol} \mathrm{dm}^{-3}, \mathrm{pH}=6.0,\left[\mathrm{Mn}^{\mathrm{II}}\right]=7.28 \times 10^{-6} \mathrm{~mol} \mathrm{dm}^{-3}$, Temp. $=35 \pm 0.01{ }^{\circ} \mathrm{C}$, acetone $=10.0 \%(\mathrm{v} / \mathrm{v}), \lambda_{\max }=470 \mathrm{~nm}$

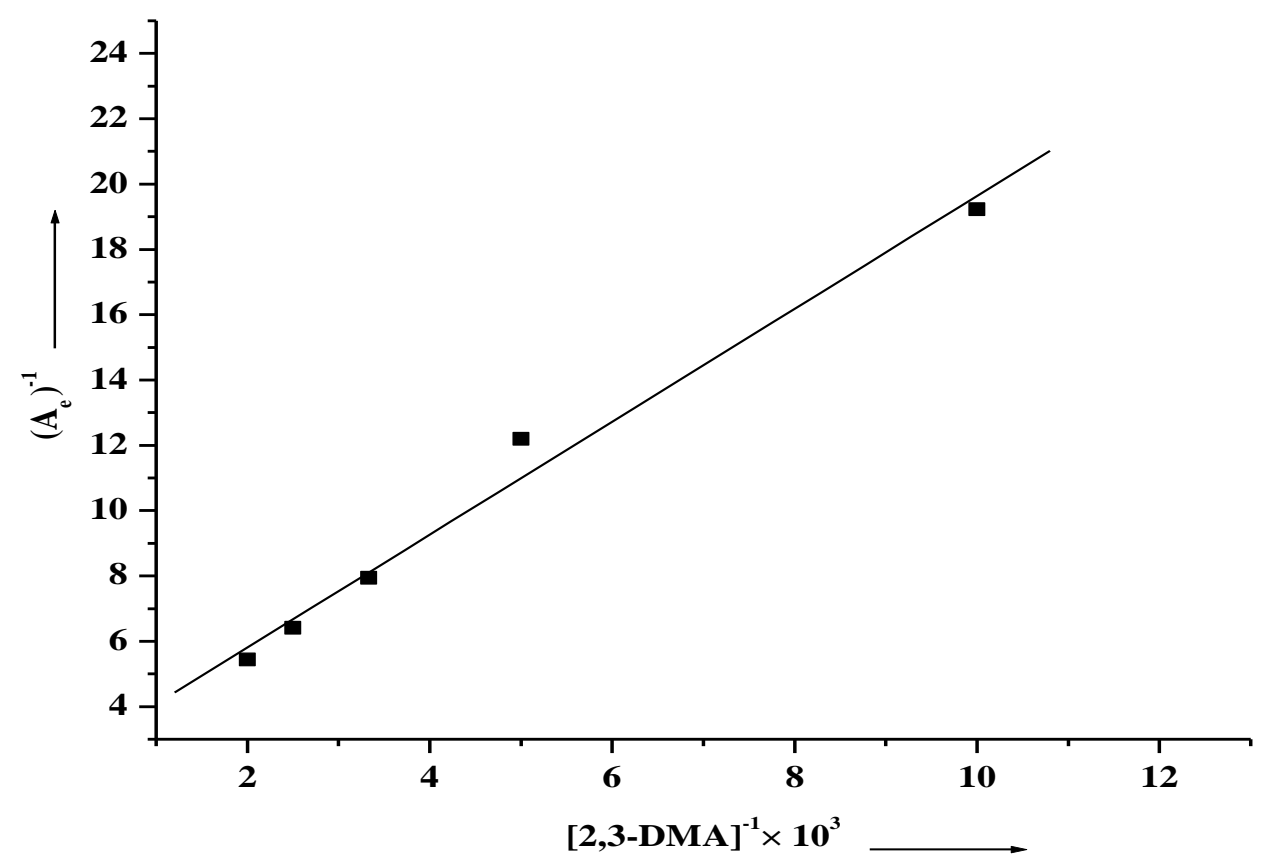

Figure 6. Plot $\left(A_{e}\right)^{-1} \mathrm{vs}[\mathrm{D}]^{-1}$ at $\left.\left[\mathrm{NaIO}_{4}\right)\right]=1.0 \times 10^{-2} \mathrm{~mol} \mathrm{dm}^{-3}, \mathrm{pH}=6.0,\left[\mathrm{Mn}^{\Pi}\right]=7.28 \times 10^{-6} \mathrm{~mol} \mathrm{dm}^{-3}$, Temp. $=35 \pm 0.01{ }^{\circ} \mathrm{C}$, Acetone $=10.0 \%(\mathrm{v} / \mathrm{v}), \lambda_{\max }=470 \mathrm{~nm}$ 
mixing $\mathrm{Mn}^{\mathrm{II}}$ and $\mathrm{D}$ and no absorbance was found at chosen wavelength i.e. $470 \mathrm{~nm}$. Further, there was absorbance noted and recorded when all the three, i.e. I, $\mathrm{Mn}^{\mathrm{II}}$ and $\mathrm{D}$ were mixed. Therefore, under the experimental conditions of this study, the binary complex, $\mathrm{Mn}^{\mathrm{II}}-$ $\mathrm{D}$, has no absorbance at chosen wavelength $(470 \mathrm{~nm}) . A_{e}$ can be assumed to be the absorbance due to ternary complex only.

If $A_{e}$ is absorbance of ternary complex, $C_{2}$, and $\mathcal{E}$ is its molar absorptivity then for cell of path length $1 \mathrm{~cm}$, we have:

$$
A_{e}=\mathcal{E}\left[\mathrm{C}_{2}\right]
$$

where $\left[\mathrm{C}_{2}\right]$ is the concentration of the ternary complex at time $t$. When whole of the manganese(II), i.e., $\left[\mathrm{Mn}^{\mathrm{II}}\right]_{0}$, is present as complex, then observed absorbance is equal to $A_{\infty}$. So replacing the values of $A_{e}$ by $A_{\infty}$ and $\left[\mathrm{C}_{2}\right]$ by $\left[\mathrm{Mn}^{\mathrm{II}}\right]_{0}$ in Equation (12), we obtain:

$$
\begin{aligned}
& A_{\infty}=\left[\mathrm{Mn}^{\Pi}\right]_{0} . \mathcal{E} \\
& \text { or } \\
& {\left[\mathrm{Mn}^{\mathrm{II}}\right]_{0}=A_{\infty} / \mathcal{E}}
\end{aligned}
$$

Substituting the value of $\left[\mathrm{C}_{2}\right]$ and $\left[\mathrm{Mn}^{\mathrm{II}}\right]_{0}$ into Equation (11) from Equations (13) and (12).

$$
A_{e} / \mathcal{E}=A_{\infty} / \mathcal{E}-A_{e} / \mathcal{E} K[\mathrm{D}][\mathrm{I}]
$$

which on rearrangement becomes Equation (14):

$$
1 / A_{e}=1 / A_{\infty} K[\mathrm{D}][\mathrm{I}]+1 / A_{\infty}
$$

This equation assumes that no species other then ternary complex absorbs at chosen wavelength, $470 \mathrm{~nm}$.

Table 2. Effect of variation of concentration of reactants on the reaction rate. $\left[\mathrm{Mn}^{\mathrm{II}}\right]=$ $7.28 \times 10^{-6} \mathrm{~mol} \mathrm{dm}^{-3}, \mathrm{pH}=6.0$, Temp. $=35 \pm$ $0.01{ }^{\circ} \mathrm{C}$, acetone $=10.0 \%(\mathrm{v} / \mathrm{v}), \lambda_{\max }=470 \mathrm{~nm}$

\begin{tabular}{ccc}
\hline $\begin{array}{c}{\left[\mathrm{NaIO}_{4}\right]} \\
\mathrm{mol} \mathrm{dm}^{-3}\end{array}$ & {$[\mathrm{D}] \mathrm{mol} \mathrm{dm}^{-3}$} & $\begin{array}{c}10^{2} k_{\text {obs }} \\
\left(\mathrm{s}^{-1}\right)\end{array}$ \\
\hline 0.010 & 0.0002 & 2.64 \\
0.015 & 0.0002 & 2.75 \\
0.020 & 0.0002 & 2.83 \\
0.025 & 0.0002 & 2.92 \\
0.030 & 0.0002 & 3.02 \\
\hline 0.010 & 0.0001 & 2.56 \\
0.010 & 0.0002 & 2.64 \\
0.010 & 0.0003 & 3.21 \\
0.010 & 0.0004 & 3.68 \\
0.010 & 0.0005 & 3.93 \\
\hline
\end{tabular}

The values of $A_{e}$ were determined first at different concentration of I and keeping [D] fixed. Under this condition Equation (14) becomes Equation (15).

$$
1 / A_{e}=1 / A_{\infty}+1 / K_{3}[\mathrm{I}] A_{\infty}
$$

Equation (15) is equivalent to Equation (14) through $K_{3}=K[\mathrm{D}]$.

In another set of experiments, the values of $A_{e}$ were determined at different concentration of [D] but at fixed concentration of [I]. Under this condition Equation (14) becomes:

$$
1 / A_{e}=1 / A_{\infty}+1 / K_{4}[\mathrm{D}] A_{\infty}
$$

A comparison of Equations (14) and (16) shows $K_{4}=K[\mathrm{I}]$.

As required by Equation (15), the plot of $1 / A_{e}$ versus $1 /[\mathrm{I}]$ is a straight line as shown in Figure 5. This plot yields slope, $\mathrm{S}_{1}=8.0 \times 10^{-2}$ and intercept, $\mathrm{I}_{1}=6.25$. According to equation (15), $\mathrm{S}_{1}=1 / K_{3} A_{\infty}$ and $\mathrm{I}_{1}=1 / A_{\infty}$. So from the ratio, $\mathrm{I}_{1} / \mathrm{S}_{1}$, the value of $K_{3}$ was found to be 78 .

Likewise, from Figure 6, we obtain, slope, $\mathrm{S}_{2}$ $=1.71 \times 10^{-3}$ and intercept, $\mathrm{I}_{2}=2.07$. Equation (16) shows $K_{4}=\mathrm{I}_{2} / \mathrm{S}_{2}$. From the values of $\mathrm{S}_{2}$ and $\mathrm{I}_{2}$, we obtain $K_{4}=1.2 \times 10^{3}$.

Now from the $K_{4}$ value of $1.2 \times 10^{3}$ (at [I] $=$ $0.01 \mathrm{~mol} \mathrm{dm}^{-3}$ ), which is equal to $K[\mathrm{I}]$, the value of $K$ was found to be $1.2 \times 10^{5}$. On the other hand from the $K_{3}$ value of 78 (at [D] $=2 \times$ $10^{-4} \mathrm{~mol} \mathrm{dm}^{-3}$ ), which is equal to $K[\mathrm{D}]$, the value of $K$ is found to be $3.1 \times 10^{5}$.

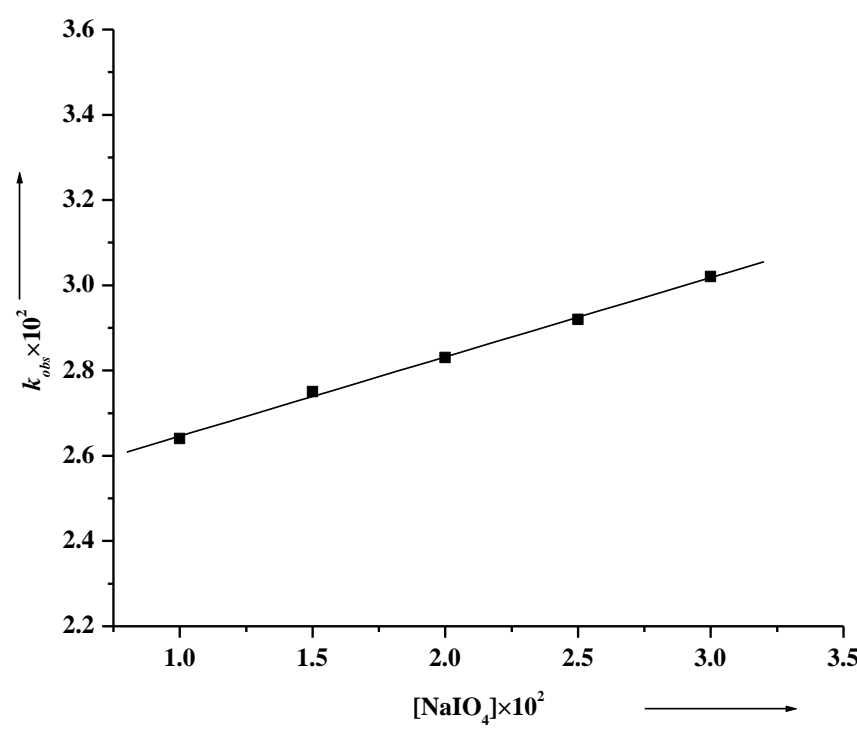

Fig. 7. $k_{o b s}$ vs $[\mathrm{I}]$ plot at $[\mathrm{D}]=2.0 \times 10^{-4} \mathrm{~mol}$ $\mathrm{dm}^{-3},\left[\mathrm{Mn}^{\mathrm{II}}\right]=7.28 \times 10^{-6} \mathrm{~mol} \mathrm{dm} \mathrm{dm}^{-3}$, $\mathrm{pH}=6.0$, Temp. $=35 \pm 0.01^{\circ} \mathrm{C}$, acetone $=$ $10.0 \%(\mathrm{v} / \mathrm{v}), \lambda_{\max }=470 \mathrm{~nm}$ 
The excellent agreement between the $K$ values, as determined from the $[\mathrm{I}]$ and [D] variations at fixed $\left[\mathrm{Mn}^{\mathrm{I}}\right]_{0}$, validates the hypothesis regarding the formation of ternary complex. The average value of $K$ is $(2.2 \pm 1.0) \times 10^{5}$ at $\mathrm{pH}$ $=6.0,\left[\mathrm{Mn}^{\mathrm{II}}\right]_{0}=7.28 \times 10^{-6} \mathrm{~mol} \mathrm{dm}-3$ and $35^{\circ} \mathrm{C}$.

\subsection{Kinetics of Ternary Complex Forma- tion}

The complete profile of a kinetics run is shown in Figure 4. As indicated earlier, the reaction occurs in two stages the second stage is relatively slow. The first stage represents possibly the formation of ternary yellow complex, for which the stability constant determination has just been described.

In section 3.1, It has already been mentioned that the reaction has been shown to be first order in I, Mn ${ }^{\mathrm{II}}$ and $\mathrm{D}$ as already reported [23]. Therefore, in present case, the kinetics was studied under pseudo first order conditions. The kinetics of the formation of the com- plex was studied at $470 \mathrm{~nm}$ under pseudo first order conditions with [I] being in excess over [D] and $\left[\mathrm{Mn}^{\mathrm{II}}\right]_{0}$ both and [D] being in excess over $\left[\mathrm{Mn}^{\mathrm{I}}\right]_{0}$. Under these conditions, the ternary complex formation follows the pseudo first order kinetics and the values of pseudo first order rate constant, $k_{o b s}$, are given in Table 2 . Some first order plots are given in Figures 7 and 8 .

The value of $k_{\text {obs }}$ appear to be only dependent on [D] \& [I] which were in excess as compared to $\left[\mathrm{Mn}^{\mathrm{II}}\right.$. $k_{\text {obs }}$ may be defined by the Equation 17.

$$
k_{o b s}=k_{f}[\mathrm{I}]+k_{r}
$$

where $k_{f}$ and $k_{r}$ are empirical rate constants as defined later. As required by Equation (17), the plot of $k_{o b s}$ versus [I] is linear as shown in Fig. 13. From this plot, the value of $k_{f}$ and $k_{r}$ were found to be $0.19 \mathrm{l} \mathrm{mol}^{-1} \mathrm{~s}^{-1}$ and $2.5 \times 10^{-2} \mathrm{~s}^{-1}$, re-

Table 3. Data Analysis for [Mn' $\left.{ }^{\mathrm{II}}-\mathrm{D}-\mathrm{I}\right]$ ternary complex formation

\begin{tabular}{|c|c|c|c|c|c|c|c|}
\hline $\begin{array}{c}{[\mathrm{I}]} \\
\mathrm{mol} \mathrm{dm} \mathrm{dm}^{-3}\end{array}$ & $\begin{array}{c}{[\mathrm{D}]} \\
\mathrm{mol} \mathrm{dm} \mathrm{m}^{-3}\end{array}$ & Plot & $\begin{array}{c}k_{r} \\
\text { (Intercept) }\end{array}$ & $\begin{array}{c}k_{f}{ }^{\prime} \\
\text { (slope) } \\
=k_{f} K_{1}[\mathrm{D}]\end{array}$ & $\begin{array}{c}k_{f}^{\prime} \\
\text { (slope) } \\
=k_{f} K_{1}[\mathrm{I}]\end{array}$ & $\begin{array}{l}10^{-3} \\
k_{f} K_{1}\end{array}$ & $\begin{array}{l}10^{-5} \\
k_{f} K_{1} / k_{r}\end{array}$ \\
\hline variation & $2 \times 10^{-4}$ & $k_{o b s}$ Vs [I] & $2.46 \times 10^{-2}$ & 0.19 & - & 1.0 & 0.40 \\
\hline $1.0 \times 10^{-2}$ & variation & $k_{o b s}$ vs [D] & $2.07 \times 10^{-2}$ & - & 37.69 & 3.8 & 1.80 \\
\hline
\end{tabular}

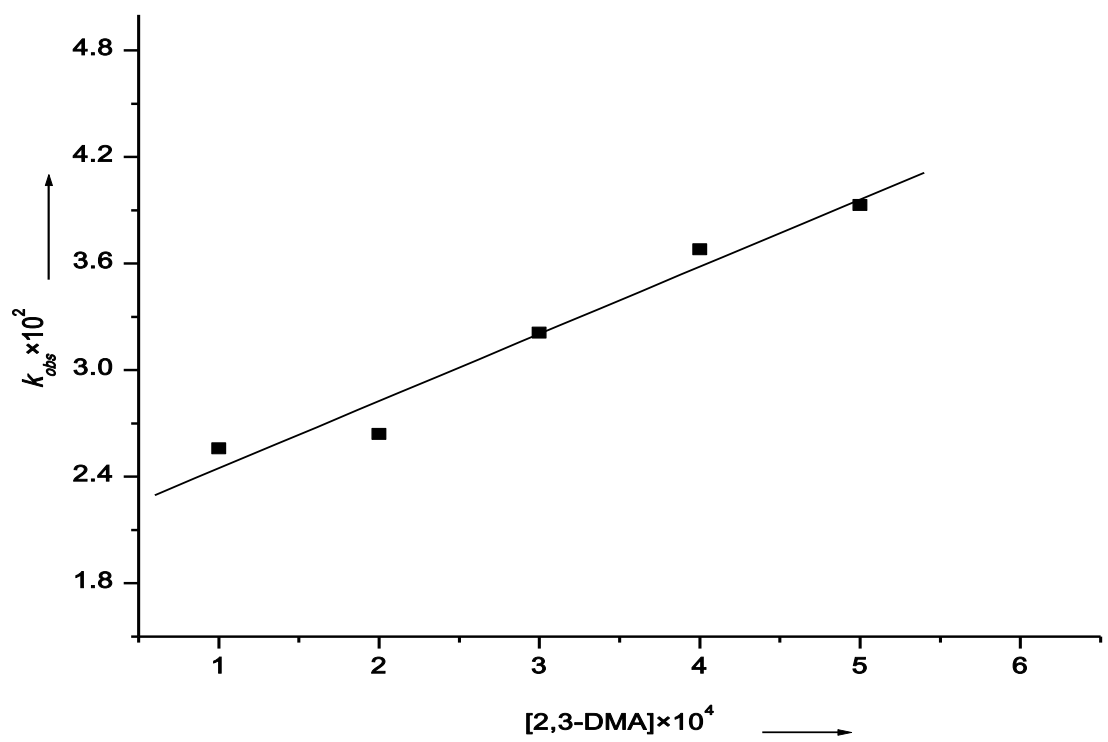

Figure 8. $k_{o b s}$ vs $[\mathrm{D}]$ plot at $[\mathrm{I}]=1.0 \times 10^{-2} \mathrm{~mol} \mathrm{dm}^{-3},\left[\mathrm{Mn}^{\mathrm{II}}\right]=7.28 \times 10^{-6} \mathrm{~mol} \mathrm{dm}^{-3}, \mathrm{pH}=6.0, \mathrm{Temp}=35$ $\pm 0.01{ }^{\circ} \mathrm{C}$, acetone $=10.0 \%(\mathrm{v} / \mathrm{v}), \lambda_{\max }=470 \mathrm{~nm}$ 
spectively.

\subsection{Mechanism of the Reaction}

The kinetics results of ternary complex formation may be explained by the mechanism (Equations 2-3), which is decidedly not unique. It is possible to write one or more alternative mechanisms to explain the results obtained in this study.

The rate of formation of $\mathrm{C}_{2}$ is given by:

$$
\mathrm{d}\left[\mathrm{C}_{2}\right] / \mathrm{dt}=k_{f}\left[\mathrm{Mn}^{\mathrm{II}} \cdot \mathrm{D}\right][\mathrm{I}]-k_{r}\left[\mathrm{C}_{2}\right]
$$

where $\left[\mathrm{C}_{2}\right]$ is the concentration of the ternary complex at time $t$.

By mass balance:

$$
\left[\mathrm{Mn}^{\mathrm{II}}\right]_{0}=\left[\mathrm{Mn}^{\mathrm{II}}\right]+\left[\mathrm{Mn}^{\mathrm{II}} \cdot \mathrm{D}\right]+\left[\mathrm{C}_{2}\right]
$$

Assuming that the concentration of $\mathrm{Mn}^{\mathrm{II}}$ - D is very small, and then on neglecting it, Equation (19) becomes Equations (20).

$$
\left[\mathrm{Mn}^{\mathrm{II}}\right]_{0}=\left[\mathrm{Mn}^{\mathrm{II}}\right]+\left[\mathrm{C}_{2}\right]
$$

Assuming that equilibrium for the formation of the binary complex, $\mathrm{Mn}^{\mathrm{II}}-\mathrm{D}$, is rapidly established then the value of concentration of $\mathrm{Mn}^{\mathrm{II}}$ $\mathrm{D}$ is given by Equation (21).

$$
K_{1}=\left[\mathrm{Mn}^{\mathrm{II}} . \mathrm{D}\right] /\left[\mathrm{Mn}^{\mathrm{II}}\right][\mathrm{D}]
$$

Substituting $\left[\mathrm{Mn}^{\mathrm{II}}-\mathrm{D}\right]=K_{1}\left[\mathrm{Mn}^{\mathrm{II}}\right][\mathrm{D}]$ in Equation (18), we get:

$$
\mathrm{d}\left[\mathrm{C}_{2}\right] / \mathrm{d} t=k_{f} K_{1}\left[\mathrm{Mn}^{\mathrm{II}}\right][\mathrm{D}][\mathrm{I}]-k_{r}\left[\mathrm{C}_{2}\right]
$$

On substituting $\left[\mathrm{Mn}^{\mathrm{II}}\right]=\left[\mathrm{Mn}^{\mathrm{II}}\right]_{0}-\left[\mathrm{C}_{2}\right]$ from Equation (20) in Equation (22), we get:

$$
\mathrm{d}\left[\mathrm{C}_{2}\right] / \mathrm{dt}=k_{f} K_{l}\left[\mathrm{Mn}{ }^{\mathrm{II}}\right]_{0}[\mathrm{D}][\mathrm{I}]-\left[\mathrm{C}_{2}\right]\left(k_{f} K_{l}[\mathrm{D}][\mathrm{I}]+k_{r}\right)
$$

If the ternary complex formation attains equilibrium then, $\mathrm{d}\left[\mathrm{C}_{2}\right] / \mathrm{d} t=0$ and $\left[\mathrm{C}_{2}\right]=\left[\mathrm{C}_{2}\right]_{\mathrm{eq}}$, where $\left[\mathrm{C}_{2}\right]_{\text {eq }}$ is the concentration of ternary complex at equilibrium. Under these conditions Equation (23) becomes Equation (24).

$k_{f} K_{3}\left[\mathrm{Mn}^{\mathrm{I}}\right]_{0}[\mathrm{D}][\mathrm{I}]=\left[\mathrm{C}_{2}\right]_{\mathrm{eq}}\left(k_{f} K_{1}[\mathrm{D}][\mathrm{I}]+k_{r}\right)$

Now from Equations (23) and (24), we get:

$\mathrm{d}\left[\mathrm{C}_{2}\right] / \mathrm{dt}=\left(k_{f} K_{1}[\mathrm{D}][\mathrm{I}]+k_{r}\right)\left(\left[\mathrm{C}_{2}\right]_{\mathrm{eq}}-\left[\mathrm{C}_{2}\right]\right)$

which on modification becomes:

$$
\mathrm{d}\left[\mathrm{C}_{2}\right] / \mathrm{dt}=k_{o b s}\left(\left[\mathrm{C}_{2}\right]_{\mathrm{eq}}-\left[\mathrm{C}_{2}\right]\right)
$$

where:

$$
\begin{aligned}
& k_{o b s}=k_{f} K_{1}[\mathrm{D}][\mathrm{I}]+k_{r} \\
& \text { or } \\
& k_{o b s}=k_{f}^{\prime}[\mathrm{I}]+k_{r}
\end{aligned}
$$

where $k_{f}=k_{f} K_{1}[\mathrm{D}]$. On integrating Equation (26), we get:

$$
\ln \left\{\left[\mathrm{C}_{2}\right]_{\mathrm{eq}} /\left(\left[\mathrm{C}_{2}\right]_{\mathrm{eq}}-\left[\mathrm{C}_{2}\right]\right)\right\}=k_{\text {obs }} . t
$$

According to Equation (27) the plot of $k_{\text {obs }}$ versus [I] (at constant [D]) is straight line with a intercept $=k_{r}$ and slope $=k_{f} K_{l}[\mathrm{D}]$ (Figure 7).

Likewise, from Equation (27) the plot of $k_{o b s}$ versus [D] (at constant [I]) is also straight line with intercept $=k_{r}$ and slope $=k_{f} K_{l}[\mathrm{I}]$ (Figure $8)$. The values of slopes and intercepts determined from these Figures are given in Table 3.

Using the values of intercepts and slopes of plots in Figures 7 and 8 , the values of $k_{f} \cdot K_{1}$ were found to be $1.0 \times 10^{3}$ and $3.8 \times 10^{3} \mathrm{dm}^{6}$ $\mathrm{mol}^{-2} \mathrm{~s}^{-1}$ from periodate and 2,3-dimethylaniline variations, respectively. Likewise, the values of $k_{f} K_{1} / k_{r}$ determined from same figures were found to be $0.4 \times 10^{5}$ and $1.8 \times 10^{5} \mathrm{dm}^{6} \mathrm{~mol}^{-2}$. The good agreement between the parameters determined from two different variations support the mechanism and the rate law proposed.

\section{Conclusion}

Stopped flow kinetics of $\mathrm{Mn}^{\mathrm{II}}$ catalysed periodate oxidation of 2,3-dimethylaniline(D) in acetone-water medium and equilibrium absorbances have been used for the first time for evaluation of stability constant of the ternary intermediate unstable complex being formed in this reaction. The stability constant evaluated for $\mathrm{D}-\mathrm{MnII}^{\mathrm{II}} \mathrm{IO}_{4}$ - ternary complex is $(2.2 \pm 1.0)$ $\times 10^{5}$. Based on the proposed mechanism of formation of this complex, the rate law under pseudo first order conditions is: $\ln \left\{\left[\mathrm{C}_{2}\right]_{\mathrm{eq}} /\right.$ ( $\left.\left.\left[\mathrm{C}_{2}\right]_{\text {eq }}-\left[\mathrm{C}_{2}\right]\right)\right\}=k_{\text {obs }} . t$, where, $k_{\text {obs }}$ is the pseudo first order rate constant, $\left[\mathrm{C}_{2}\right]$ is concentration of ternary complex at given time $t,\left[\mathrm{C}_{2}\right]_{\mathrm{eq}}$ is the equilibrium concentration of ternary complex. The value of stability constant is in good agreement with that obtained from the proposed rate law.

\section{Acknowledgements}

The authors are thankful to Gurukul Kangri University, Haridwar, India for providing necessary facilities for undertaking this work. 


\section{References}

[1] Mortensen, S.K., Trier, X.T., Foverskov, A., Petersen, J.H. (2005). Specific determination of 20 primary aromatic amines in aqueous food stimulants by liquid chromatographyelectrospray ionization-tendem mass spectrometry. J. Chromatogr. A., 1091: 40-50.

[2] Pinheiro, H.M., Touraud, E., Thomas, O. (2004). Aromatic amines from azo dye reduction: status review with emphasis on direct UV spectrophotometric detection in textile industry wastewaters. Dyes and Pigments. 61: 121-139.

[3] Dupret, J.M., Dairou, J., Busi, F., Silar, P., Martins, M., Mougin, C., Lima, F.R., Cocaign, A. (2011). Pesticide-Derived Aromatic Amines and Their Biotransformation, in: Stoytcheva, M., (Ed.), Pesticides in the Modern World Pests Control and Pesticides Exposure and Toxicity Assessment. InTech, Croatia, 601614.

[4] Gupta, V.K. (1985). Kinetics and mechanism of oxidation of $\mathrm{p}$-substituted anilines by peroxydisulphate ion in acetic acid-water medium. React. Kinet. Catal. Lett., 27: 207-211.

[5] Mansoor, S.S., Shafi, S.S. (2014). Oxidation of some para-substituted anilines by benzimidazolium fluorochromate in aqueous acetic acid medium-A kinetic and mechanistic study. Arab. J. Chem., 7: 171-176.

[6] Pavolva, V.K., Sevchenko, Ya.S., Yatsimiriskii, K.B. (1970). Kinetics and mechanism of oxidation of diethylaniline by periodate. Zh. Fiz. Khim., 44: 658-663.

[7] Kaushik, R.D., Kumar, V., Arya, R.K., Singh, D. (2000). Periodate oxidation of o-toluidine in acetone-water medium - A kinetic and mechanistic study. Asian J. Chem., 12: 1123-1128.

[8] Kaushik, R.D., Singh, R.P., Shashi. (2003). A kinetic-mechanistic study of periodate oxidation of $p$-chloroaniline. Asian J. Chem., 15: 1485-1490.

[9] Kaushik, R.D., Malik, R., Kumar, A. (2010). Kinetics and Mechanism of periodate oxidation of $o$-anisidine in acetone-water medium. J. Indian Chem. Soc., 87: 317-323.

[10] Kaushik, R.D., Kumari, R., Kumar, T., Singh, P. (2010). Periodate oxidation of N,Ndimethylaniline and $\mathrm{N}, \mathrm{N}$ - diethylaniline. Asian J. Chem., 22: 7959-7968

[11] Kaushik, R.D., Arya, R.K., Kumar, S. (2000). Periodate oxidation of aromatic amines: Kinetics and Mechanism of oxidation of $\mathrm{N}$ ethylaniline in acetone-water medium. Asian J. Chem., 12: 1229-1234

[12] Kaushik, R.D., Kumar, V. Kumar, S. (1999). Periodate oxidation of N-methylaniline in ace- tone-water medium- A kinetic and mechanistic study. Asian J. Chem., 11: 633-638

[13] Kaushik, R.D., Joshi, R. Singh, D. (1998). Periodate oxidation of aromatic amines --- studies on the role of substituents and linear free energy relationships. Asian J. Chem., 10: 567572

[14] Kaushik, R.D., Oswal, S.D., Singh, D. (2000). A kinetic and mechanistic study of periodate oxidation of o-ethylaniline in acetone-water medium. Asian J. Chem., 12: 1129-1134

[15] Kaushik, R.D., Singh, D., Joshi, R., Kumar, S. (1998). Kinetics of periodate oxidation of aromatic amines - studies on the kinetic parameters and isokinetic relationship for few anilines. Asian J. Chem., 10: 573-576

[16] Kaushik, R.D., Joshi, R. (1997). Kinetics and mechanism of periodate oxidation of $\mathrm{m}-$ toluidine in acetone - water medium. Asian J. Chem., 9: 527-532

[17] Kaushik, R.D., Singh, J., Manila, Kaur, M., Singh, P. (2014). Kinetics and Mechanism of $\mathrm{Mn}^{\mathrm{II}}$ Catalyzed Periodate Oxidation of $p$ anisidine: Effect of $\mathrm{pH}$. Bull. Chem. React. Eng. Catal. 9(3): 182-191 (DOI: 10.9767/bcrec.9.3.6823.182-191)

[18] Kaushik, R.D., Shashi, Amrita, Devi, S. (2004). Kinetics and mechanism of $\mathrm{Mn}$ (II) catalysed periodate oxidation of 4-chloro-2methyl aniline. Asian J. Chem.16: 818-822.

[19] Kaushik, R.D., Kumar, D., Kumar, Anuj., Kumar, Ajay. (2010). Manganese(II) catalysed oxidation of 2,4-xylidine by periodate-A kinetic-mechanistic study. J. Indian Chem. Soc., 87: 811-816.

[20] Kaushik, R.D., Kaur, M., Malik, R., Kumar, A. (2010). Studies on Manganese(II) catalysed oxidation of $\mathrm{N}$-methylaniline by periodate ion. Int. J. Chem. Sci., 8: 1379-1388.

[21] Kaushik, R.D., Kumar, A., Kumar, T., Singh, P. (2010). Manganese(II) catalysed periodate oxidation of p-toluidine- A kinetic-mechanistic study. React. Kinet. Mech. Catal., 101: 13-23.

[22] Kaushik, R.D., Malik, R., Kumar, T., Singh, P. (2012). Manganese(II) catalysed periodate oxidation of 2-amino-m-xylene-A KineticMechanistic Study. Oxid. Commun., 35: 316326.

[23] Kaushik, R.D., Malik, R., Agarwal, R., Singh, J. (2014). Kinetics and Mechanism of $\mathrm{Mn}^{\mathrm{II}}$ catalyzed periodate oxidation of 2, 3-xylidine in acetone-water medium. Res. J. Pharm. Biol. Chem. Sci., 5: 1644-1653.

[24] Britton, H.T.S. (1956). Hydrogen ions, D. Von Nostrand Co. 354.

[25] Conklin, M.H., Hoffmann, M.R. (1988). Metal Ion-Sulfur (IV) Chemistry. 3. Thermodynam- 
ics and Kinetics of Transient Iron(III)-Sulfur(

IV) Complexes. Environ. Sci. Technol., 22: 899-907.
[26] Gupta, K.S., Jain, U., Singh, A., Dhayal, Y., Rani, A. (2012). Kinetics of palladium(II)catalysed oxidation of sulfur(IV) by oxygen. $J$. Indian Chem. Soc., 89: 1035-1043. 